\title{
A City in Quest of an Appropriate Antiquity: The Arena of Verona and Its Influence on Architectural Theory in the Early Modern Era
}

\author{
Hubertus Günther
}

Some curious observations led me to the argument of this contribution. Firstly, in Sebastiano Serlio's book on Roman antiquities - precisely, in its second edition - I found the comment on the Arena of Pola that

the manner of this articulation is obviously very different from those used in Rome, and I for my part would not adopt members such as those of the Amphitheatre in Rome in my works, but would willingly avail myself of those of the building in Pola, as they are done in a better manner and are better conceived, and I am sure that this was done by a different architect and that by chance he [i.e. the one of the Coliseum] he was a German, because the members of the Coliseum have something of the German manner. ${ }^{1}$

'German manner' (maniera tedesca) was the usual term for the style of medieval buildings generally despised in Italy at that time, and German in this context means Germanic. As was well known in the Renaissance, the Roman amphitheatre called the Colosseum had been built under Vespasian some ten years before Tacitus wrote his famous account of the Germanic tribes, reporting that they still lived in wooden huts spread out between large forests. In Serlio's time it was already an absurd idea that one of these primitives from the northern timberlands might have designed a monument as magnificent as the Colosseum.

1 'La maniera di questi corniciamenti è molto differente da quelle di Roma, come si puo vedere, \& io per me non faria cornici come quelle de l'Amphitheatro di Roma ne le mie opere: ma diquelle de l'Edificio di Pola si bene me ne serviria: perche elle sono di miglior maniera e meglio intese, e tengo per certo che quel fusse un'altro Architetto differente da questo, e per aventura questo fu Thedesco: percioche le cornici del Coliseo hanno alquanto de la maniera tedesca': Sebastiano Serlio, Il terzo libro, nel qual si figurano e descrivono le antiquita di Roma e le altre che sono in Italia e fuori d'Italia (Venice, Francesco Marcolini: 1544) 78. The translations were done by the author of the present article.

(C) HUBERTUS GÜNTHER, 2019 | DOI:10.1163/9789004378216_005

This is an open access chapter distributed under the terms of the prevailing CC-BY-NC-ND License at the time of publication. 
Gradually I began to grasp what the extravagant judgement might mean when I found the copy of Serlio's book in which Vincenzo Scamozzi had inserted his own glosses. ${ }^{2}$ Scamozzi reproduces there the following 'ancient inscription' of the Arena of Verona [Fig. 3.1]:

\author{
Q. L. FLAMINEVS. COS. ROM. \\ AC. VNIVERSAE GRAECIAE DO \\ MINATOR. AMPHITHEATRVM \\ VERONAE. PROPRIIS. SVM \\ PTIBVS. A. FONDAMENTIS \\ EREXIT. ANNO. AB. VRBE \\ CONDITA. DIII. \\ Quintus Lucius Flamineus, Consul of the Romans \\ and conqueror of all Greece, erected in Verona this \\ amphitheatre by his own \\ expense from the fundaments in the year \\ 503 after the foundation of Rome. ${ }^{3}$
}

As was also well known in the Renaissance, the date 503 after the foundation of Rome (753 BC) means: in the year 250 before Christ. According to today's knowledge or to the edition of the Fasti consulares published by Carlo Sigonio in $155^{\circ}$ and revised by Onofrio Panvinio in 1558 , a consul with the same name as indicated in the "ancient inscription" did not exist in Rome at the time indicated. At best, one might think of Gaius Flaminius (consul in 223 and 218 вС), who, as a censor, had created the Via Flaminia from Rome to Ravenna and built the Circus Flaminius in Rome (220 BC), or of Lucius Quinctius Flamininus (consul in $192 \mathrm{BC}$ ), who led the administration of the province of Gallia Cisalpina and also resided in Upper Italy, who as an aedile was responsible for the organization of the ludi scenici (in 201 BC) and who was mentioned by Valerius Maximus in connection with theatres. ${ }^{4}$ Moreover, at the time indicated in the inscription, the first war against Carthage was taking place (264-241 BC), and Rome did not yet dominate the Greek world or any other territory outside

2 Cf. Günther H., "Scamozzi kommentiert Serlio", Riha-Journal, Special Issue "Vincenzo Scamozzi" (November 2012), online at http://www.riha-journal.org/articles/2012/2012-oct$\mathrm{dec} /$ special-issue-scamozzi/guenther-scamozzi-kommentiert-serlio (retrieved 18 September 2017).

3 Sebastiano Serlio, Il terzo libro (Venice, Pietro de Nicolini de Sabbio: 1551; ex libris Scamozzi) 72 (Zentralinstitut für Kunstgeschichte, Munich).

4 Valerius Maximus, Facta et memorabilia IV, 5, 1. 


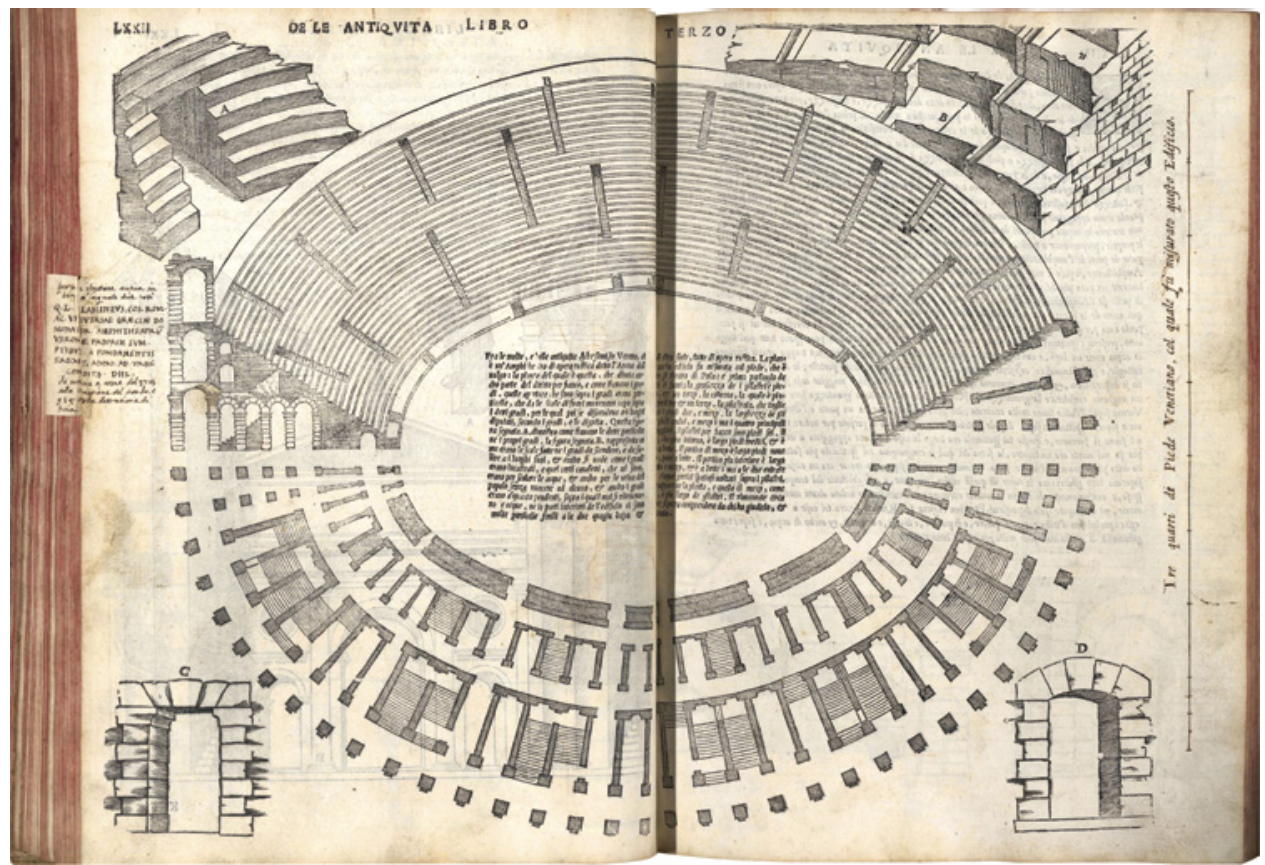

FIGURE 3.1 Arena of Verona, with the (fake) building inscription, added as a manuscript annotation by Vincenzo Scamozzi. Taken from Scamozzi's copy of Sebastiano Serlio, Il terzo libro (Venice: 1551) 72 IMAGE (C) ZENTRALINSTITUT FÜR KUNSTGESCHICHTE, MUNICH

Italy, but was still fighting to gain supremacy in Italy; during the Second Punic War Hannibal had almost conquered the city. All this was well known to Renaissance historians. these historical circumstances actually do not suggest that Rome in those days had the capacity to erect huge theatres. I will show on the following pages that the puzzle of both these curious cases can be solved when it is placed in the context of the quest for an appropriate past. ${ }^{5}$

\section{Veronese Patriotism and the Arena of Verona}

Hardly any other European city was associated with as many expressions of deep affection as Verona was. The following verses by Giovanni Cotta

5 An earlier, but partially more detailed version of my research is: Günther H., "Antike Bauten im venezianischen Hoheitsbereich. Historische Einordnung und Bewertung in der Renaissance, Einfluss auf die Säulenlehre Palladios und Scamozzis", Eirene 48 (2012) 60-81. 
(ca. 1480-1510), for example, were repeated several times in Verona during the Renaissance:

Verona, qui te viderit
Et non amarit protinus
Amore perditissimo,
Is, credo, seipsum non amat,
Caretque amandi sensibus,
Et odit omnes gratias.

Verona, who has seen you

and has not immediately fallen in love with you

with the most awesome love,

he, I think, does not love himself,

and completely lacks the ability of feeling love

and hates all grace. ${ }^{6}$

The typical declarations of love for Verona were apparently widely known in Europe. William Shakespeare, in his Romeo and Juliet, paraphrases them in the verses:

There is no world without Verona walls,

But purgatory, torture, hell itself.

Hence banished is banish'd from the world,

And world's exile is death $[\ldots] .^{7}$

These intimate verses of national love were also an expression of a nostalgic retrospect of the great past of the blissful city, once powerful but in more recent times deprived of her autonomy. During the Middle Ages, Verona was the most important metropolis between Venice and Milan, and in antiquity, as the Veronese claimed time and again, her splendour was second only to that of the Eternal City. Her many magnificent ancient monuments exuded the highest pride. The uncontested highlight was the Arena [Fig. 3.2]. ${ }^{8}$ It was

6 Mistruzzi V., "Giovanni Cotta", Giornale Storico della Letteratura Italiana suppl. 22-23 (1924) 1-131, esp. 119.

7 Shakespeare, Romeo and Juliet, act 3, scene 3; cf. D'Amico J., Shakespeare and Italy: The City and the Stage (Gainesville: 2001) 24-25. Höttemann B., Shakespeare and Italy (Vienna etc.: 2011) 184-185, 225-240. Fischer R. (ed.), Quellen zu Romeo und Julia, Shakespeares Quellen in der Originalsprache und deutsch 2 (Bonn: 1922).

8 Maffei Scipione, Verona illustrata (Verona, Jacopo Vallarsi e Pierantonio Berno: 1731-1732), vol. 4, 68-135; Coarelli F. - Franzoni L., L'arena di Verona (Verona: 1972); Arich D. - Spalviero F., 


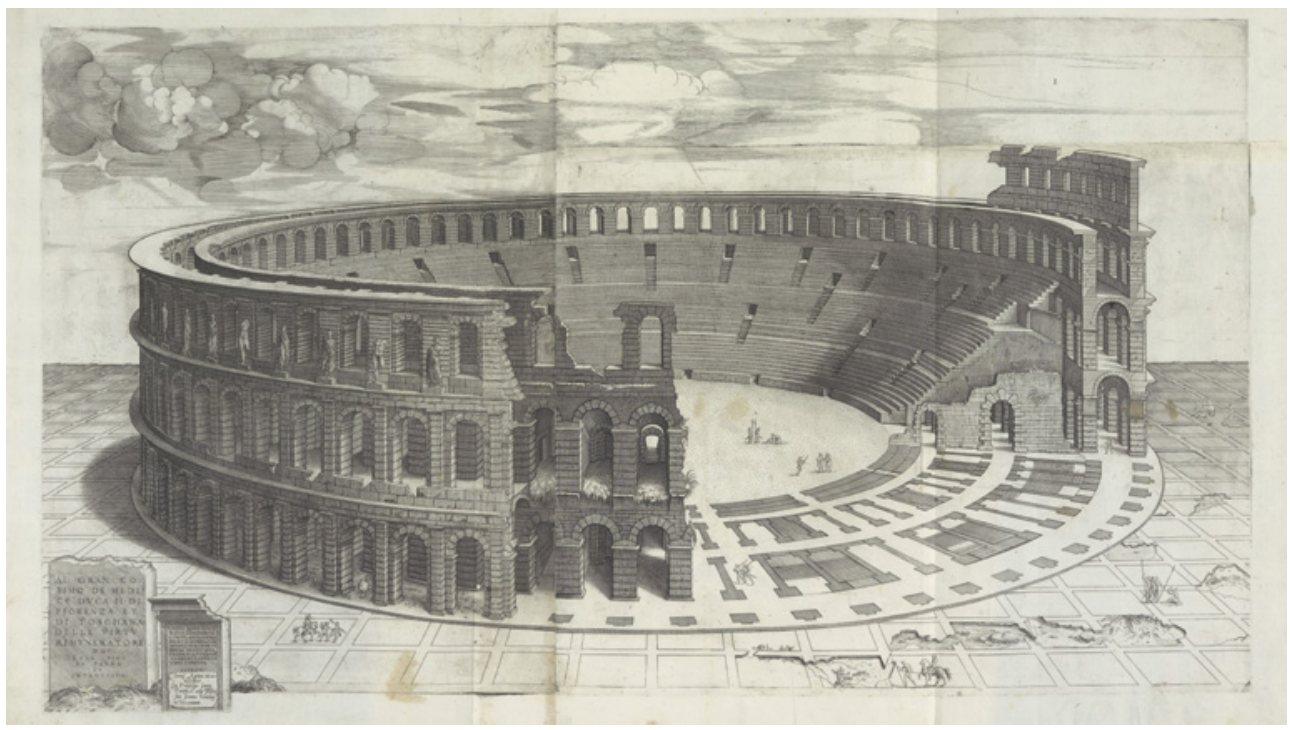

FIGURE 3.2 Enea Vico (engraver), The Arena of Verona (ca. 1550) with the (fake) building inscription (bottom left). Engraving, $5^{2.4} \times 88.2 \mathrm{~cm}$ IMAGE (C) RIJKSMUSEUM, AMSTERDAM

famous throughout Europe. In Antoine Desgodets' Les édifices antiques de Rome (1682) the Arena is the only monument outside Rome the author deems worthy of consideration. Andrea Palladio listed the arenas of Verona and Pola together with the Colosseum as being among the great monuments of Rome's flourishing period. ${ }^{9}$ The Veronese often emphasized that their Arena was barely ranked behind the Colosseum, the greatest Roman amphitheatre preserved. Pietro Donato Avogaro and similarly Giovanni Agostino Panteo even praised the Arena as

[...] this noble amphitheatre, the biggest building of all that have ever been erected by the hands of men, even destined for eternity, with which neither the miraculous pyramids can be compared [...] nor can

L'Arena diVerona:duemila annidistoria e dispettacolo (Verona:2002); Weiss R., The Renaissance Discovery of Classical Antiquity (Norwich: 1988²) 117-118.; Golvin J.-C., L'amphithéâtre Romain, vol. 1 (Paris: 1988) 169-173; Gros P., L'architecture romaine du début du IIIe siècle av. J.-C. à la fin du Haut-Empire, vol. 1 (Paris: 2002 ${ }^{2}$ ) 317-345. The graphic reproductions of the Arena are reproduced by Schweikhart G., Le antichità di Verona di Giovanni Caroto (Verona: 1977), Figs. 29-59.

9 Andrea Palladio, Scritti sull'architettura (1554-1579), ed. A. Puppi (Vicenza: 1988) 158. 
the stupendous labyrinths invented by human ingenuity [...] nor these amphitheatres which one can see in Rome or Pola.

[...] amphitheatrum illud nobile, opus maximum omnium, quae unquam fuere humana manu facta aeternitatis etiam destinatione, cui neque pyramidum miracula [...] neque labyrinthorum portentosissima humani ingenii opera neque eorum, quae Romae et Polae visuntur, comparari possunt. ${ }^{10}$

Although large parts of the outer ring wall had collapsed due to an earthquake in 1117 , Renaissance writers often referred to the Arena as the best-preserved building for spectacles because the cavea was - and still is - better preserved there than anywhere else. Here it was possible to verify what Vitruvius wrote about the cavea of theatres. One of the many foreign visitors to the Arena emphasized that here was the rare occasion to proof the acoustics of ancient theatres in reality. ${ }^{11}$ The cavea is so well preserved because the Arena was protected by the city government and used for performances even during the Middle Ages and afterwards. This tradition continues with the Opera Festivals today as an international attraction.

The outer ring wall of the Arena has three storeys of arcades [Figs. 3.2-3.4]; it is completely rusticated; in the first two floors, between the arcades there are extremely slender pilasters, while the pilasters on the third floor are either extremely broad or narrow. Based on the capitals, the entire articulation might be assigned to the Doric order, but the bases are missing and the entablatures with their rich mouldings cannot be connected with any specific order of columns.

10 Avogaro Pietro Donato, De viris illustribus antiquissimis qui ex Verona claruere, ca. 1493, ed. in Avesani R., "Il 'De viris illustribus antiquissimis qui ex Verona claruere', Italia medioevale e umanistica 5 (1962) 1-84, esp. 68-84, for the Arena: 77-78. Panteo Giovanni Agostino, De laudibus Veronae (Venice, Bernardino Vitali: 1505), fols. P Iv-IIr. Esch A., "Staunendes Sehen, gelehrtes Wissen: zwei Beschreibungen römischer Amphitheater aus dem letzten Jahrzehnt des 15. Jahrhunderts", Zeitschrift für Kunstgeschichte 50 (1987) 385-393, esp. 385-388, 392-393; idem, "Anschauung und Begriff. Die Bewältigung fremder Wirklichkeit durch den Vergleich in Reiseberichten des späten Mittelalters", Historische Zeitschrift 253 (1991) 281-312, esp. 309-311.

11 Fichard Johann, Italia (1536), ed. J.C. von Fichard, Frankfurterisches Archiv für ältere deutsche Litteratur und Geschichte 3 (1815) 129. 


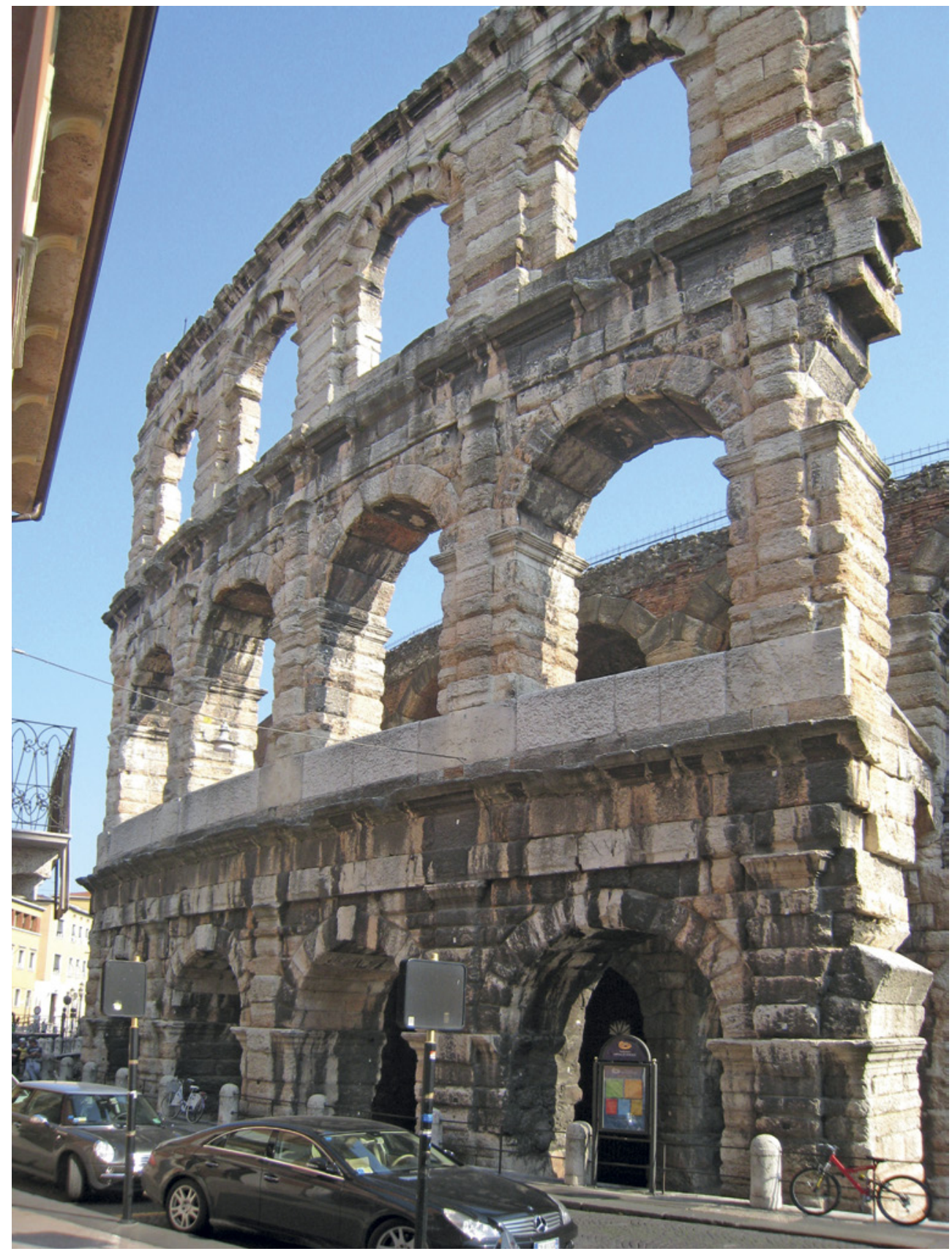

FIGURE 3.3 Arena of Verona (first half of the first century AD), remains of the outer wall IMAGE (C) AUTHOR 


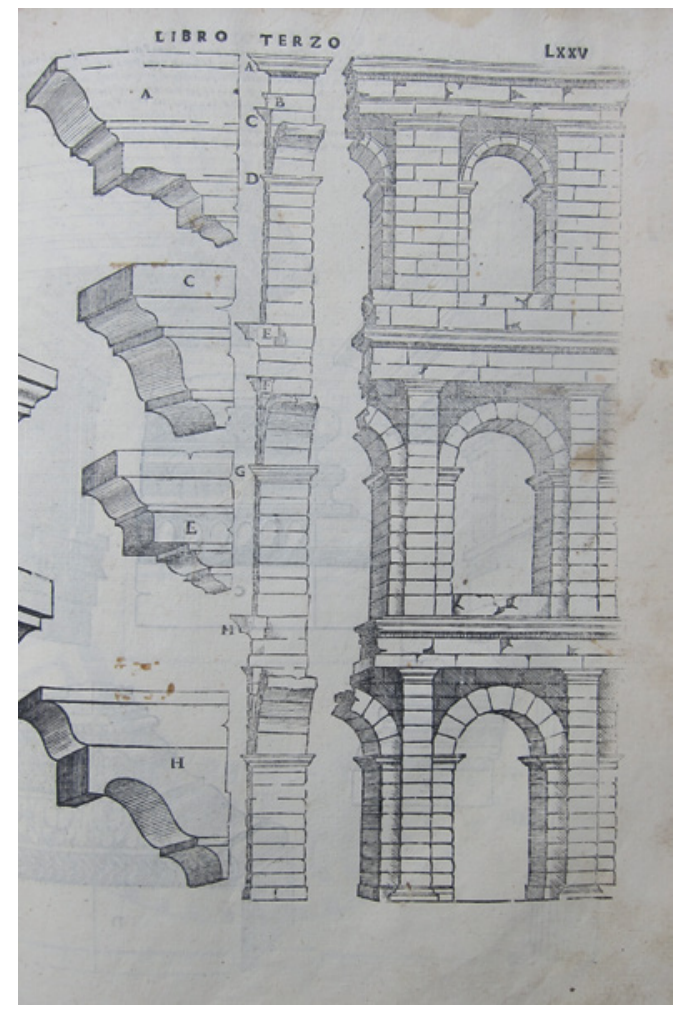

\section{FIGURE 3.4}

Arena of Verona, elevation and details of the articulation. From: Sebastiano Serlio, Il terzo libro (Venice: 1540) IMAGE (C) AUTHOR

Regarding the circumstances of the construction of the Arena of Verona, there is nothing handed down in ancient sources. Early in the fifteenth century, the Veronese were amazed at this lack of information, since otherwise ancient writings mention great monuments, such as the Colosseum. The best example of the discussion on the phenomenon may be found in the long eulogy to Verona written by Francesco Corna in 1477. It treats all the antiquities of the city; twelve whole stanzas are devoted to the Arena. ${ }^{12}$ Corna reports that the opinions about the origins of the Arena varied widely: some thought that it was built by one of the seven kings of Rome (ca. 750-500 BC) or by a Roman consul or by King Theoderic of the Ostrogoths (died 526 AD in Ravenna). Coma held that all these opinions were wrong and instead dated the Arena to the era

12 Corna da Soncino Francesco, Fioretto de le antiche croniche de Verona e de tutti i soi confini e de le reliquie che se trovano dentro in ditta citade, eds. G.P. Marchi - P. Brugnoli (Verona: 1973) 55-59, stanzas 149-161. 
of Augustus. We shall return to the dating later. However, that is not the main point of the discussion: Corna sought an explanation for the phenomenon that the Arena's founder is not known. He considers it unlikely that a single man founded this theatre; because of the magnificence of the monument, his name would be known and he would be famous as a great ruler. Corna solves the problem by this argument: 'In truth it is most probable that the people as a community had made it to exalt their native city with great praise, glory and condition, for they used to make buildings with great art everywhere.' ${ }^{13}$ I suppose that this idea derives from the Latin signature 'Senatus Populusque Romanus', which in many ancient inscriptions, official documents, and other writings rhetorically attributes the authority or the responsibility for an activity, and in particular a building initiative, to the Roman people. Even a Veronese municipal council decree of 1568 regarding a restoration of the Arena considers it most probable that the community of the Veronese citizens had constructed the Arena. ${ }^{14}$ Here, fervent patriotism created a profaned version of the medieval report of how all the people in common collaborated in the construction of the cathedral of Chartres. ${ }^{15}$

The dating of the Arena to the golden era of Augustus had its origins in the Middle Ages. The first person to adopt it during the Renaissance was Ciriaco d'Ancona, and then this practice became normal in Verona. ${ }^{16}$ This had to do with the fact that in Verona and in other northern Italian places Vitruvius was considered a native of Verona, because the Arco dei Gavi in Verona bears an inscription indicating that it had been built by an architect named Lucius Vitruvius Cerdo, and this person was identified as being the author of the

13 Corna, Fioretto, stanza 159: 'Queste cotal ragione a mi non pare / aver de fede vera conclusione, / ma inver più presto lo facesse fare / el populo per sua communione, / vogliando lor la sua patria exaltare / de grande fama, laude e condizione: / ché gli era usanza quasi in ogni parte / fare qualche edificio con grande arte'.

14 Cf. below, note 54 .

15 Letter of the Abbot Haimo of St-Pierre-sur-Dives (Calvados) to Tutbury Priory in England 1145. Kimpel D. - Suckale R., Die gotische Architektur in Frankreich 1130-1270 (Munich: 1985) 72 .

16 Ciriaco d'Ancona, Itinerarium, ed. Laurentius Mehus (Florence, Giovanni Paolo Giovannelli: 1742) 28. Cited by Sarayna Torello, De origine et amplitudine civitatis Veronae (Verona, Antonio Putelleti: 1540), fols. 13r-15r; and Panvinio Onofrio, Antiquitatum Veronensium libri VIII (Passau, Paolo Frambotto: 1648) 93-95, who also evokes a 'very old' chronicle. Maffei, Verona illustrata vol. 4, 68-69. Marchi G.P., "Ciriaco negli studi epigrafi di Scipione Maffei”, in Paci G. - Sconocchia S. (eds.), Ciriaco d'Ancona e la cultura antiquaria dell'umanesimo (Reggio nell'Emilia: 1998) 453-467, here 46o-461. Ciriaco d'Ancona visited Venice several times, and in 1423 he visited Pula, cf. Colin J., Cyriaque d'Ancône. Le voyageur, le marchand, l'humaniste (Paris: 1981) 36-38. 
famous treatise of architecture from the era of Augustus [Fig. 3.5]. ${ }^{17}$ It was not only a patriot like Francesco Corna who accepted this identification - even the critical Antonio da Sangallo did so as well when studying the monument. ${ }^{18}$ In the Renaissance, the citizens of Verona exalted the great personalities of antiquity who originated from their native town, like the ancient buildings as a badge of honour for the city. Among them were both Plinys, the authors of the Natural History and of the Letters, respectively, which were most important for architecture, too. The ancient personalities are represented by the statues on top of the Loggia del Consiglio, which was built in the late fifteenth century opposite the town hall of Verona at the Piazza dei Signori [Fig. 3.6]. Vitruvius stands over the corner of the building between the Piazza dei Signori and the main street leading from there to the cathedral. The attribution of the Arco dei Gavi was often also transferred to the Arena, at first by Ciriaco d'Ancona and Filarete, then by the Venetian historian Marino Sanudo and many others. ${ }^{19}$

In 1540, the Veronese lawyer and antiquarian Torello Sarayna published a treatise about the antiquities of Verona which was richly illustrated with large woodcuts [Figs. 3.5 and 3.7 ]. ${ }^{20}$ It was the first treatise on local antique architecture outside Rome ever printed. The book is imbued with the same passionate love for the native city as Corna's eulogy was. The above-quoted epigram by Corna is printed at the beginning of Sarayna's work. Sarayna emphasizes that only Rome is as rich in ancient monuments as Verona, and he praises the great men of ancient Verona, including Vitruvius, the author of De architectura.

As usual, Sarayna treats the Arena most extensively. ${ }^{21} \mathrm{He}$ repeats that the cavea is particularly well preserved and that only the Colosseum surpasses the Arena in size, but the Arena is more elaborate, as it is built of marble. In view of its magnificence, he also dates it to the golden era of Augustus. As with

17 Gallerani P.I., "Andrea Mantegna e Jacopo Bellini, percorsi epigrafici a confronto", Aquileia nostra 70 (1999) 177-214, esp. 191-197; Beltramini G., "Mantegna e la firma di Vitruvio", in Marini P. - Marinelli S. (eds.), Mantegna e le arti a Verona 1450-1550 (Venice: 2006) 137-144.

Gallerani, "Mantegna e Bellini" 191-197; Beltramini G., "Architetture firmate nel Rinascimento italiano", in Beltramini G. - Burns H. (eds.), L'architetto: ruolo, volto, mito (Venice: 2009) 49-66, $5^{2-53}$. For the opinion of Antonio da Sangallo on the Arco dei Gavi, cf. Uffizi, GDSU A 1382: 'Questo archo è di mano di Vetruvio ed è bellissimo'. Cf. also Vasori O., Imonumenti antichi in Italia nei disegni degli Uffizi, ed. A. Giuliano (Rome: 1981) no. 125 .

19 Ciriaco d'Ancona, Itinerarium 28. Cited by Sarayna, Verona fol. 13 v. Averlino Antonio detto il Filarete, Trattato di Architettura, ed. A.M. Finoli - L. Grassi (Milan: 1972) 337. Sanudo Marino, Itinerario di Marin Sanuto per la terraferma Veneziana nell'anno MCCCCLXXXIII, ed. R. Brown (Padua: 1847) 101.

20 Sarayna, Verona.

21 Sarayna, Verona, fols. $13 \mathrm{v}-15 \mathrm{r}$, and $37 \mathrm{v}$. 


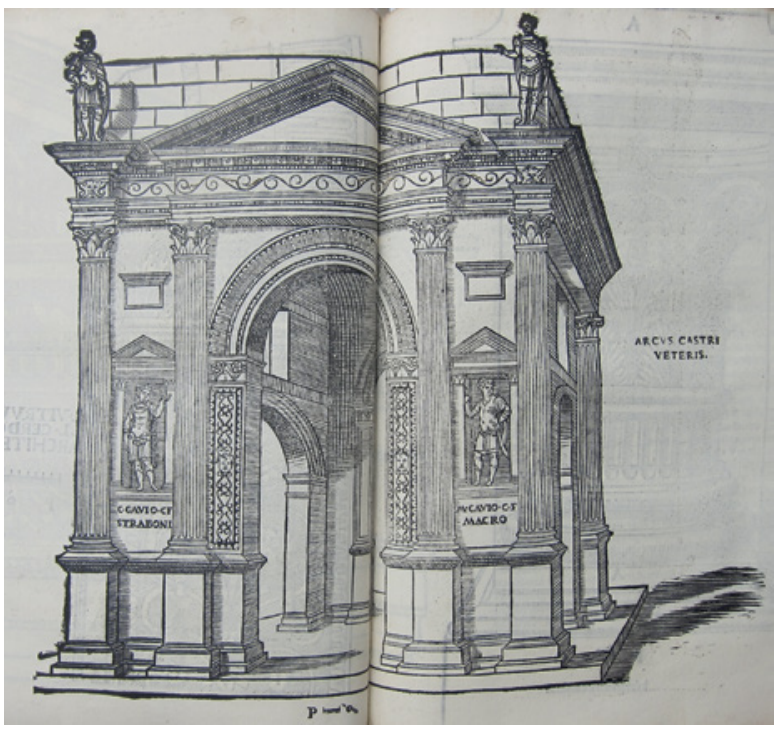

FIGURE 3.5 Arco dei Gavi, Verona. From: Torello Sarayna, De origine et amplitudine civitatis Veronae (Verona: 1540)

IMAGE (C) AUTHOR

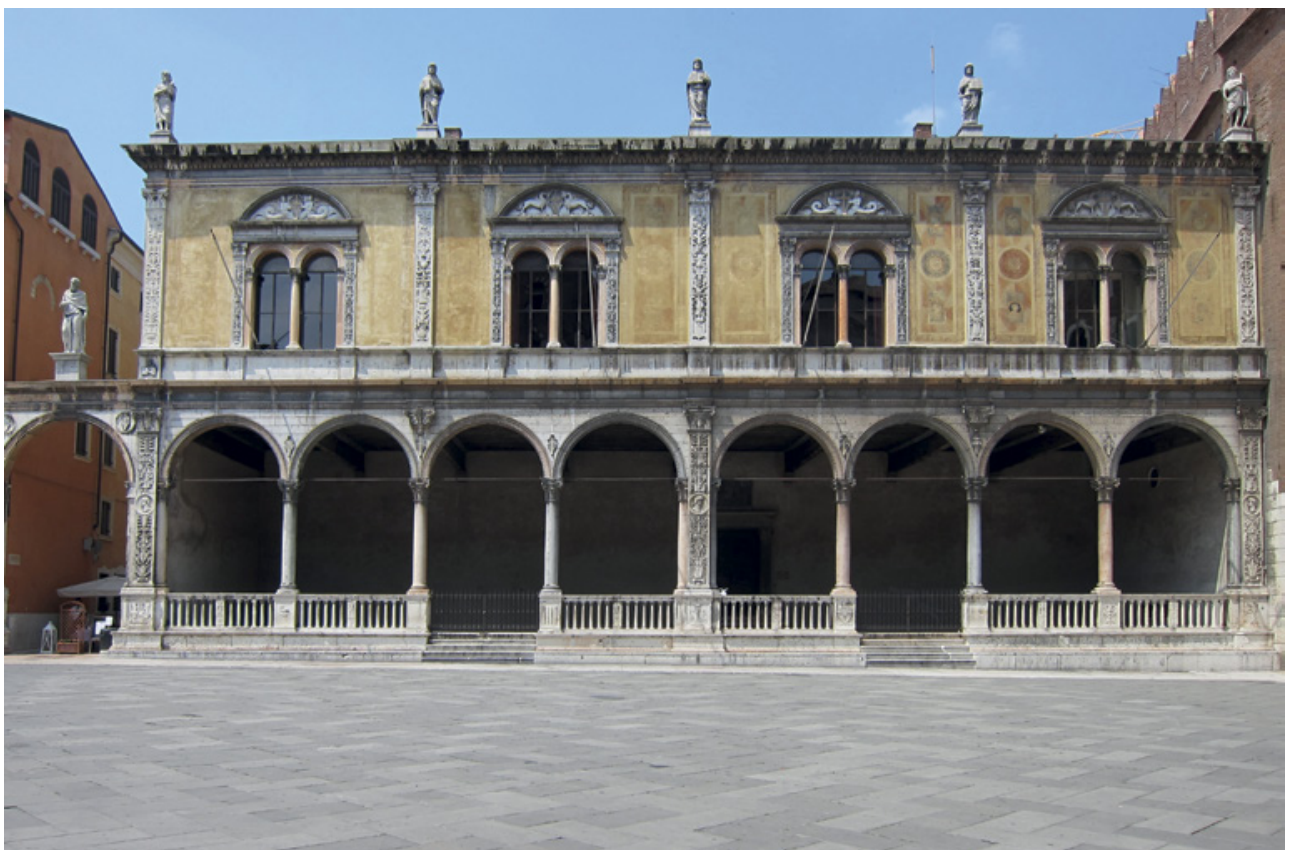

FIGURE 3.6 Verona, Loggia del Consiglio

IMAGE (C) AUTHOR 


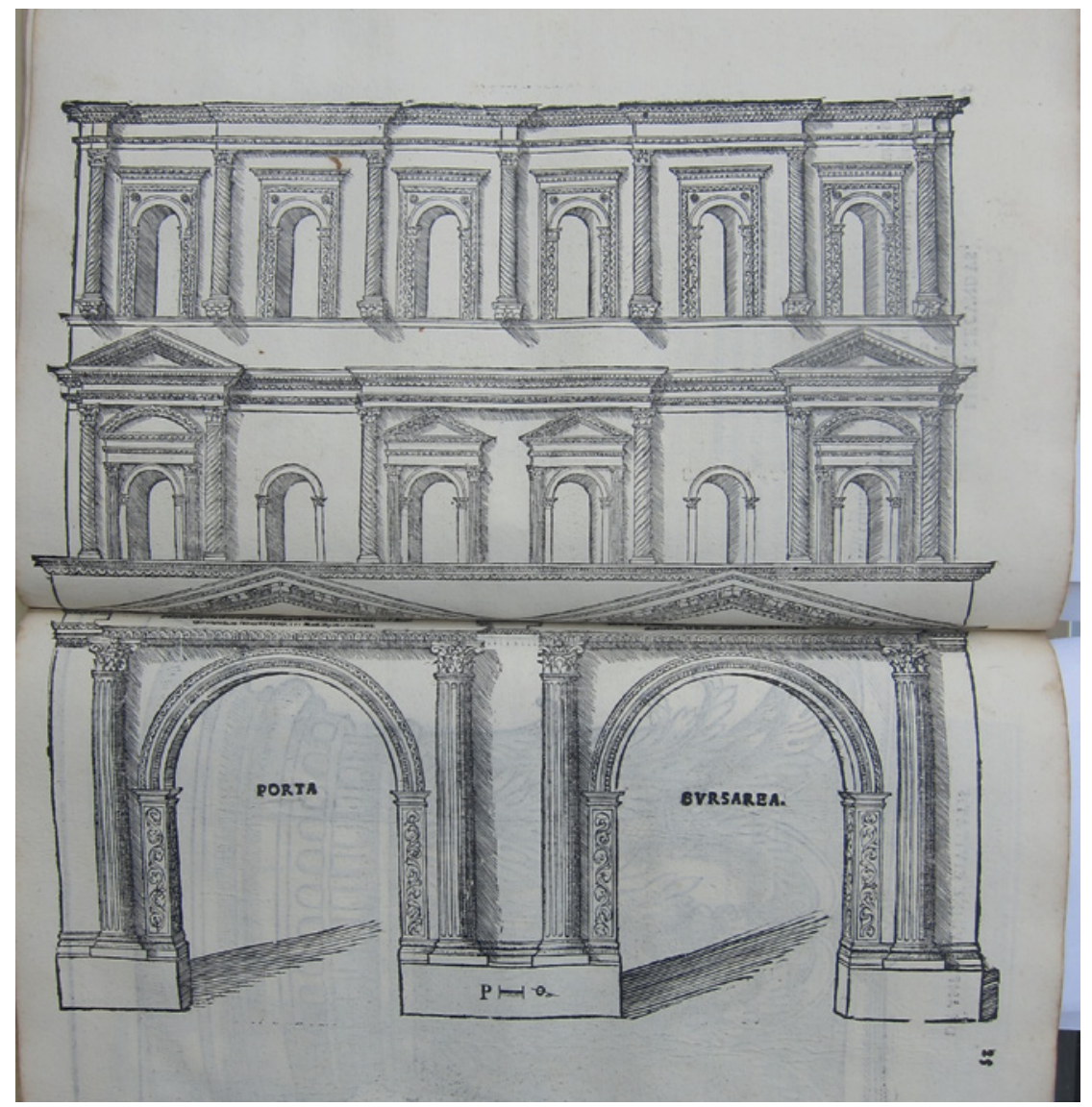

FIGURE 3.7 Porta dei Borsari. From: Verona, in Torello Sarayna, De origine et amplitudine civitatis Veronae. (Verona: 1540)

IMAGE (C) AUTHOR

Francesco Corna, it appears as a sign of the ancient freedom of Verona, since Sarayna also claims that it was founded not by a single person or Roman potentate, but by the community of citizens.

The ancient monuments also influenced the new architecture in Verona, Venice, and the Veneto. Mauro Codussi had already imitated some of its motives in Venice; Giovanni Maria Falconetto and others took the Arco dei Gavi as a model for the unusual idea of signing their own buildings. ${ }^{22}$ Michele Sanmicheli imitated elements of the Arena and the Porta dei Borsari [Fig. 3.7].

22 Burns H., "Le antichità di Verona e l'architettura del Rinascimento", in Marini P. (ed.), Palladio e Verona, exh. cat. (Verona: 1980) 103-118. Beltramini, "Architetture firmate" 54-61. 
The Palazzo Bevilacqua is the main example of this: it adopts on the ground floor the articulation of the Arena, with its slender rusticated pilasters, and upstairs it takes on that of the nearby Porta dei Borsari, with its special window frames and spiral fluting of the columns.

\section{Sebastiano Serlio's Opinion on the Arena of Verona}

This ideal world was disrupted by Sebastiano Serlio after he had settled in Venice. He had become famous as a theorist of architecture for his book on the orders of columns published in 1537, which was the first profound treatise dedicated to that matter. Before he moved to Venice, he had lived in Rome, where he thoroughly studied the ancient monuments. A few months before Sarayna's book appeared, Serlio published his work on the antiquities of Rome and of all Italy, which would remain a classic in the field until the end of the seventeenth century. ${ }^{23}$ As he states explicitly, the main aim of this work was to teach its readers how to differentiate between good and bad architecture. ${ }^{24}$ In his presentations of the ancient buildings, he evaluates them. Thereby the ancient buildings of Verona come off quite badly. Serlio rejects the claim that Vitruvius was the architect of the Arco dei Gavi, ${ }^{25}$ and by consequence also the assumption that he was a native from Verona and might have built the Arena is cancelled. Moreover, Serlio criticizes some monuments of Verona for violating the classical rules. He disqualifies the Porta dei Borsari of being so 'barbaric' that it was not even worthy of being recorded in his book at all [Fig. 3.7]. ${ }^{26}$

The Arena, however, was too famous to be so overtly attacked. Therefore, Serlio makes a detour: he only remarks briefly that the Arena is made in the same style as the Arena of Pola. ${ }^{27}$ This makes sense [Figs. 3.4 and 3.8]. But then Serlio delivers the verdict that was quoted already above in a later, distorted version:

23 Serlio Sebastiano, Il terzo libro, nel qual si figurano \& descrivono le antichità di Roma \& le altre, che sono in Italia \& fuori d'Italia (Venice, Francesco Marcolini: 1540).

24 Günther H., "Sebastiano Serlios Lehrprogramm", in Boschetti-Maradi A. - Kersten W. (eds.), Fund-Stücke - Spuren-Suche, Zurich Studies in the History of Art 17/18 (Berlin: 2011) 494-517.

25 Serlio, Il terzo libro (1540 edition) 131.

26 Serlio, Il terzo libro (1540 edition) 141.

27 Regarding the architectural members: 'le quali hanno forma diversa da quelle di Roma, e paion de la maniera di quelle de l'Amphitheatro di Pola'. Serlio, Il terzo libro (1540 edition) 74 . 


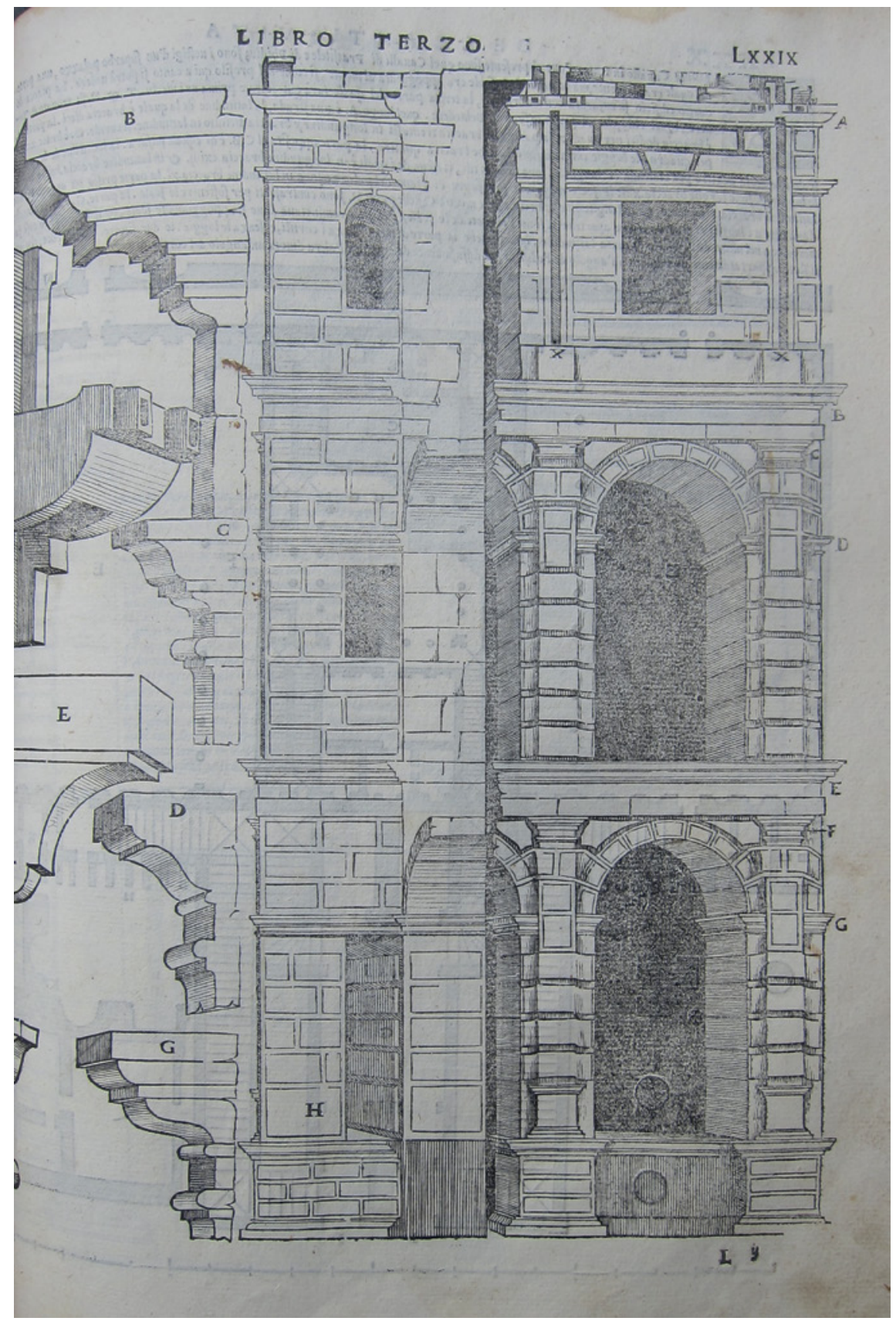

FIgURE 3.8 The Arena of Pola, elevation und details of the articulation. From: Sebastiano Serlio, Il terzo libro (Venice: 1540) IMAGE (C) AUTHOR 
The manner of this articulation [of the Arena] is obviously very different from that used in Rome and I for my part would not adopt such members in my works, but avail myself willingly of those of the Theatre in Pola, as they are of a better manner and better conceived; I am sure that this was a different architect than this one; and by chance he was a German, because the members have something of the Germanic manner (maniera tedesca). ${ }^{28}$

Please observe the slight but grave differences from the text of the distorted version: in the original version a Germanic architect should have built not the Colosseum, but the arena of Pola, and hence that of Verona. In the next chapter I will discuss the reason for this change.

I suppose that in the original context Serlio did not intend to refer to the Germanic tribes as described by Tacitus, but to the Ostrogoths, who settled in northern Italy and Dalmatia during the sixth century. It was well known in the Renaissance that the king of the Ostrogoths, Theoderic the Great, had established a residence in Verona. ${ }^{29}$ This fact was distorted during the Middle Ages into the legend that Theoderic had built the arenas of Verona and Pola and had even dwelt there. ${ }^{30}$ The Arena of Verona was also known as 'the palace of Theoderic'. As mentioned above, Francesco Corna reports this as one of the opinions about the person who had built it and it was repeated by many foreign visitors of Verona during the Renaissance. It was particularly attractive for German visitors because they identified Theoderic with Dietrich of Bern, the hero of the Nibelungen saga who was king of 'Bern' or 'Dietrichsbern' - the old German name for Verona. In 1521, Count Palatine Ottheinrich still remarked during his visit in Verona:

28 Serlio, Il terzo libro (1540 edition) 78: 'la maniera di questi corniciamenti è molto differente da quelle di Roma, come si puo vedere ed io per me non faria tal cornice [instead of 'cornici come quelle de l'Amphitheatro di Roma', as in the edition of 1544] ne le mie opere: ma di quelle del theatro [instead of: 'de l'Edificio' of the 1544 edition] di Pola si bene me ne servira: perche elle sono di miglior maniera e meglio intese, e tengo per certo che quel fusse un'altro Architetto differente da questo e per aventura questo fu Tedesco: percioche le cornici [missing: 'del Coliseo'] hanno alquanto de la maniera tedesca'.

29 Cassiodorus, Variae X, 27; XII, 27. Procopius, Bellum Gothicum II, 12. Excerpta Valesiana 71. Cf. the articles 'Theoderich', 'Verona', and 'Ticinum' in Pauly-Wissowas Realencyklopädie des Classischen Altertums; Flavio Biondo, Italia illustrata (Basel, Officina Frobeniana: 1531) 345; idem, Le historie da la declinatione de l'Impero di Roma insino al tempo suo, trans. L. Fauno (Venice, Michele Tramezzino: 1543-1550), vol. I, fols. 24r, 25r, and $178 \mathrm{v}$. Coarelli - Franzoni, Arena di Verona 69-70. Esch, "Staunendes Sehen" 390. 


\section{[...] I have seen a great Colosseum, in which Dietrich of Bern dwelt..}

Someone who was able to found complex buildings, such as S. Vitale and the Mausoleum in Ravenna, could also be trusted to have built the arenas of Verona and Pola. However, the casual expression 'per avventura questo fu Tedesco' (by chance this was a German) suggests that behind the attribution of the arenas to an Ostrogothic architect Serlio hid some irony about the medieval Veronese tradition.

Torello Sarayna reacted furiously to Serlio's book on ancient buildings. On the back side of the title page of his book Sarayna had printed a warning to the reader. It states that a certain Sebastianus Sergius from Bologna had published a book in which he treats some monuments of Verona along with many antiquities, but as he had not seen them for himself, he had either carelessly deformed what he had taken over from others, or had consciously distorted it. ${ }^{32}$

Sarayna was a powerful personality. Even today, his sumptuous tomb and the huge altar screen erected by him in S. Fermo in Verona hold up his wealth before our eyes. Serlio would suffer for having degraded the monuments of Verona. One year after the publication of his book on ancient buildings, he was promoted far away from Venice, in France, with the help of Pietro Aretino. Guillaume Philandrier, while staying in Venice as the secretary of the French ambassador there, had worked amicably with Serlio, but in 1544 in his commentary on Vitruvius he distanced himself from Serlio because he had published his book on ancient buildings very precipitously. ${ }^{33}$ Then followed such a stream of criticism that Egnazio Danti wrote some forty years later: 'I do not

$31 \quad$ Hertzog Ott Heinrichs raißbeschreibung in Palaestinam, ed. and trans. in Reichert F., Die Reise des Pfalzgrafen Ottheinrich zum Heiligen Land 1521 (Regensburg: 2005) 102-243, here 108-109: 'unndt hab do geseh<en> ein große Colise, do der Berner in gewohnt hat'. Indicated to me courtesy of Hanns Hubach.

32 'Hic te admonendum lector putavimus, quod ante hanc nostram impressionem, quidam Sebastianus Sergius [sic] Bononiensis inter multorum locorum antiquitates, quarum volumen ab se compositum dedit, Veronensium etiam monumentorum aliquot se antiquarium professus est, quae, quia ipse non vidit, imprudenter fortasse ab alterius incuria sumpta, aut non recte designavit, aut non cognita subticuit. [...]'.

33 Philandrier Guillaume, In decem libros M. Vitruvii Pollionis de architectura annotationes (Rome, Giovanni Andrea Dossena: 1544) 137. 
know any architect who would not extensively use his works, although I have seen few who do not criticize these works'. ${ }^{34}$

In 1544 the second edition of Serlio's book on ancient buildings was published. As Serlio was absent from Italy then, the publisher could eliminate the derogatory treatment of the Arenas of Pola and Verona. He did so by redirecting Serlio's attribution regarding a German architect from the Arena of Pola towards the Colosseum. In this way the bizarre attribution of the Colosseum to a German architect came into being. Although the frivolous substitution is just a joke that evokes the evil tongue of Pietro Aretino, it remained in all later Italian editions of Serlio's book on ancient buildings, but it usually was not adopted in the translations published in foreign countries.

However, Serlio's critical attitude could not be easily dismissed after some great architects had come to northern Italy who, like Serlio, had been shaped by the classicism of the Roman High Renaissance: Michele Sanmicheli returned to Verona, Jacopo Sansovino was appointed state architect of Venice, and Giulio Romano had moved to Mantua as court architect. The Doric articulations, which all three of them used in many buildings, usually follow the rules established in Rome and are in obvious contrast to the articulation of the Arena of Verona. The identification of the architect of the Arco dei Gavi with the author of the Augustean architectural treatise became obsolete after the curators of its major editions, Fra Giocondo and Cesariano, had abandoned it. Also Philandrier agreed with their opinion.

\section{5 Dating of the Arena in Early Periods of Italian Architecture}

Nevertheless, there remained a way to save the honour of the Arena. This path branches out from the two other old opinions that Francesco Corna reports on the origins of the Arena, namely that it was founded either by one of the kings of Rome or by a Roman consul. The "seven mythical kings of Rome" means the seven mythical kings of Rome from the Etruscan period, i.e. from Romulus to Tarquinius Superbus. It was well known that the Etruscans also populated parts of northern Italy. Flavio Biondo already stated that they had founded Mantua. ${ }^{35}$ I suppose that Leon Battista Alberti wanted to revive this heritage with his idea of giving S. Andrea in Mantua the form of an Etruscan

\footnotetext{
34 Barozzi da Vignola Jacopo, Le due regole della prospettiva practica, ed. E. Danti, (Rome, Francesco Zannetti: 1583) 82: '[...] nessuno Architetto ho mai conosciuto, il quale non si serva grandemente dell'opere sue, se bene rari n'ho visti, da'quali dette opere non siano biasimate'.

Biondo, Italia illustrata (Basel, Officina Frobeniana: 1531) 36o.
} 
temple. ${ }^{36}$ Sarayna tries to prove in detail that the Etruscans also founded Verona. For this, he refers to the fragments of the Elder Cato's Origines; however, he did not refer to what is known of the work today, but to one of the forgeries that Annio da Viterbo edited together with his notorious Berosus falsification in 1498 and to which many Italian humanists, as well as Scamozzi, gave credence. ${ }^{37}$

The early dating apparently belongs in the context of the competition between cities for the oldest tradition. In Italy as well as elsewhere, many cities claimed that Trojan heroes had founded them; so, in the vicinity of Verona, Padua had her origins traced back to Antenor. Therefore, the Veronese could not but pretend that the foundations of their city had been laid before the Fall of Troy and before Antenor came to Italy. ${ }^{38}$ Sarayna argued that Verona had originated in Babylonian times. ${ }^{39}$ Marin Sanuto writes in 1483 that Shem, a son of Noah, had built the first city of Verona. ${ }^{40}$ As Sarayna further reports furthermore, during recent construction works, caves were discovered in Verona that looked just like those Vitruvius had described as the earliest dwellings of mankind. ${ }^{41}$ Thus, the first human beings might have settled in the place. About the same time as, Corna composed his elegy on Verona, Sigismund Meisterlin wrote his chronicle of Augsburg in which he gave a vivid description of the life the descendants of Noah's son Japhet led in Europe and how they began to build primitive dwellings. ${ }^{42}$

About the Roman consul whom some believed to be the founder of the arena of Verona, Francesco Corna stated that he was involved in the battles of Bedriacum (69 AD), from which Vespasian emerged as the victor and subsequently rose to the rank of emperor. ${ }^{43}$ However, the consul then took on an

$36 \quad$ Krautheimer R., "Alberti's templum etruscum", Münchner Jahrbuch der bildenden Kunst 12 (1961) 65-73.

37 M. Porcius Cato, "Fragmenta ex libris originum", in Fragmenta vetustissimorum auctorum summo studio ac diligentia nunc recognita, ed. Annio da Viterbo (Basel, Johannes Bebel: 1530) 6; Nanni Giovanni, Le antichità di Beroso Caldeo sacerdote. Et d'altri scrittori cosi Hebrei, come Greci, Latini, che trattano delle stesse materie, trans. F. Sansovino (Venice, Altobello Salicato: 1583) 62.

38 Valerini Adriano, Le bellezze di Verona. Nuovo ragionamento (Verona, Girolamo Discepoli: 1586) 8.

39 Sarayna, Verona fol. $5 \mathrm{v}$.

$40 \quad$ Sanuto, Itinerario 96.

41 Sarayna, Verona fol. $7 \mathrm{r}$.

42 Meisterlin Sigismund, Ein schöne Cronick und Hystoria, wye nach der Synndtfluß Noe die teutschen, das streitpar volck, iren anfang enpfangen haben (Augsburg, Melchior Ramminger: 1522), fol. $4 \mathrm{v}$.

43 Sartori F., "Un fabbro umanista del '40o: Francesco Corna da Soncino", in Accademia di agricoltura, scienze e lettere di Verona (ed.), Il Territorio Veronese in età Romana. Convegno del 22-23-24 ottobre 1971: atti (Verona: 1973) 691-727, esp. 721-722. 
entirely different identity. The new version was advanced in a debate about the Arena which was conducted in 1526 during a dinner at the court of Marquis Federico II of Mantua. Perhaps it was Giulio Romano who raised the issue, as he had just begun building the Palazzo Tè on behalf of the Marquis. The rustica that he had extensively adopted to decorate the palace might have attracted the interest of the courtiers in the Arena of Verona, and perhaps Giulio, as a scholar of Raphael, had already criticized the articulation of the monument. The Count Ludovico Nogarola, a learned gentleman from Verona who had been brought to the court of Mantua by the future Cardinal Ercole Gonzaga, was then asked who had founded the Arena, and answered in a way that seems to have been intended to protect the monument of his hometown against such criticism: a monk, he said, had indicated to him that at S. Frediano in Lucca there was a building inscription commemorating as the founder a person named L.Q. Flaminius. After he had returned to Verona, the count wrote a letter to the marquis where he records the discussion for posterity and strengthens his answer by reproducing in extenso the inscription that Scamozzi later annotated on Serlio's representation of the Arena (albeit with some small variations) - thus proving the great antiquity of the monument. ${ }^{44}$

Although its magnificence suggested a date in the Augustean era for the Arena, apparently it was also imaginable that such a building had already been built in the early days of Rome. Sarayna reports that theatres and amphitheatres were already common in Greece and Italy before the Romans seized power, and this was still confirmed by Scamozzi. ${ }^{45}$ Statilius Taurus erected the first amphitheatre in Rome ( $29 \mathrm{BC})$, but ancient writings report that a gladiator battle was fought in Rome as early as 264 BC and that circuses had existed in Rome as early as in the time of the kings and the republic: King Tarquinius Priscus founded the Circus Maximus, while the censor and later consul C. Flaminius Nepos founded the Circus Flaminius only ca. 30 years after

44 'L. Q. Flaminius roman. cons. ac universae / Greciae domitor, Amphitheatrum Veronae / Sumptibus propriis a fundamentis erexit/ Anno ab urbe condita DIII': Archivio di Stato Mantova, A.G., Busta 156o. Biadego G., "Una falsa iscrizione intorno all' Anfiteatro di Verona", Atti della R. Accademia delle Scienze di Torino 40 (1904-1905) 86-93. Brown C.M., "The decoration of the private apartment of Federico II Gonzaga on the pianoterreno of the Castello di San Giorgio", in Belfanti C.M. - D'Onofrio F. - Ferrari D. - Guerre C.M. (eds.), Stati e Città. Mantova e l'Italia Padana dal secolo XIII al XIX (Mantua: 1988) 315343, esp. 326.

45 Copy of a draft of Scamozzi's fourth book of the Idea, on theatres, in the Biblioteca Bertoliana, Vicenza, MS 3314, p. 4. Lippmann W., "Frammenti del manoscritto inedito del Iv libro dell'Idea della architettura universale: i due capitoli su teatri e anfiteatri”, in Barbieri F. - Beltramini G. (eds.), Vincenzo Scamozzi 1548-1616 (Venice: 2003) 479-482: '[...] l'uso degli Amphitheatri pare antichissimo non solo appresso a Greci [...]'. 
the alleged creation of the Arena of Verona by the consul Quintus Flaminius. ${ }^{46}$ The shape of the circuses is not mentioned, but Pliny's description of the legendary grave of King Porsenna testifies that a colossal Etruscan monument already existed around 500 BC. ${ }^{47}$ Daniele Barbaro writes in his comment on Vitruvius that Vitruvius had treated the Etruscan way of building, because architecture did arise first by the Etruscans and because their kings had built many generous monuments and buildings. ${ }^{48}$ In the Palazzo d'Arco at Mantua, Giovanni Maria Falconetto depicted the appearance of Mutius Scaevola before Porsenna against the background of an amphitheatre similar to the Arena of Verona (ca. 1515). ${ }^{49}$

The foundation inscription of the Arena of Verona is a fake..$^{50}$ As initially mentioned, it contains obvious inconsistencies. Its strange location far from Verona, in Lucca, and the monk from Lucca as reporter of the inscription seem to have been invented as a classical rhetorical device to absolve Count Nogarola from responsibility for the fake. Verona as the native town of Felice Feliciano was a centre of humanistic epigraphy and of inventing ancient inscriptions. ${ }^{51}$ I doubt whether the count was really serious about the inscription. His story might as well have been an intellectual play, as they were common in the courtly societies of the Renaissance. Mantua was a centre of courteous culture, and vivid testimonies of the wit cultivated there have been passed down. ${ }^{52}$

Anyway, for a long time nothing more was heard of the faked inscription. Sarayna and some later authors do not take it into account. The Antiquitates Veronenses by the great historian Onofrio Panvinio (1529-1568), and an engraving published in 1560 in Rome by Antonio Lafreri retained Sarayna's dating of the Arena to the Augustean era. ${ }^{53}$ Afterwards, a dating even to late antiquity

46 Livy, History III, 54, 15.

47 Pliny, Naturalis historia xxxvI, 91, 93. Fane-Saunders P., Pliny the Elder and the Emergence of Renaissance Architecture (Cambridge: 2016) 271-275.

48 Barbaro Daniele, I dieci libri dell'architettura di M. Vitruvio (Venice, Francesco de' Franceschi - Christoforo Chrieger: 1567) 193.

49 Signorini R., Il palazzo d'Arco in Mantova: da casa a museo (Mantua: 2016) 52-88.

$50 \quad C I L \mathrm{~V}, 1,36-42$, no. 411.

51 Mitchell C., "Archaeology and Romance in Renaissance Italy", in Jacob E.F. (ed.), Italian Renaissance Studies (London: 1960) 455-483, here 480-481; idem, "Felice Feliciano", Proceedings of the British Academy 47 (1961) 197-221. Grafton A., Forgers and Critics: Creativity and Duplicity in Western Scholarship (London: 1990).

52 Cf., for example, Günther H., "Badekultur in der italienischen Renaissance", in Deutsch K. - Echinger-Maurach C. - Krems E.-M. (eds.), Höfische Bäder in der Frühen Neuzeit (Berlin - Boston 2017) 25-45, esp. 39, 43-44.

53 Schweikhart, Antichità di Verona Fig. 46. Panvinio, Antiquitatum Veronensium 93. 
emerged. ${ }^{54}$ However, in $155^{0}$ the historian Leandro Alberti from Bologna published the faked inscription in his scholarly guidebook of Italy, which had ten further editions in Venice until 1631, as well as two German translations. ${ }^{55} \mathrm{He}$ presents the fake as a serious document and deduces from it that the Arena is very old. From then on, the false inscription appeared again and again in books and illustrations as a basis for dating the Arena of Verona [Fig. 3.2]. In 1560 Giovanni Caroto, who had supplied the illustrations in Sarayna book on the antiquities of Verona, inserted it in his own picture book The Antiquities of Verona, which he had published with the intention to 'represent the grandeur and inestimable magnificence of his hometown' as, no less than Sarayna's, also 'his soul was always inflamed to make himself and his nation immortal'. ${ }^{6}$ Even the Veronese municipal council decree of 1568 regarding a restoration of the Arena mentions the consul as its founder. ${ }^{57}$ In this frame belongs the gloss of

54 Sigonio Carlo, Historiarum de Occidentali Imperio libri XX (Basel, Thomas Guarini: 1579) 30.

55 Alberti Leandro, Descrittione di tutta Italia (Bologna, Anselmo Giaccarelli: 1550), fol. 413r: 'L. V. Flaminius Rom. Cons. ac universae Graeciae Domitor, Amphitheatrum Veronae propriis sumptibus erexit Anno ab Urbe Condita. D.III'. Marijke Ottink (Commission for the edition of the Thesaurus Linguae Latinae, Bayerische Akademie der Wissenschaften) indicated to me a somewhat strange article by Ridolfi M., "Sopra alcuni quadri di Lucca restaurati: ragionamento quinto", Atti della R. Academia Lucchese di scienze, Lettere ed Arti 14 (Lucca: 1853) 299-391, esp. 306-308. There, the inscription published by Leandro is quoted in the following manner: 'L. Q. Flaminius C. / Ac universae Graeciae domitor / Amphitheatrum..... /......... Veronae / S ....... /An. ab Urbe cond ... DIV..... According to Ridolfi, Alberti filled the lacunae as follows: '[...] / Amphitheatrum hoc / Sicut illud Veronae / Suis expensis fieri curavit / Anno ab Urbe condita DLXIII' (emphasis mine). In reality, this deviates from Leandro's transcription. There is no explanation for Ridolfi's version.

56 Caroto Giovanni, De le antiquità de Verona con nuovi agionti (Verona, Paolo Ravagnan: 1560). Schweikhart, Antichità di Verona pl. 6o; preface: 'Essendomi gia molto per spasso \& utilita dell'architettura et anchora dilettato di investigar, ritrovar \& ritrar in disegno anticaglie di molte sorti \& havendone abundantemente ritrovate nella patria mia, le quali in molti modi mi hanno dato maraviglia, parte per bellezza \& artificioso lavoro, ch'io ho veduto \& notato in quelle, parte perche da loro mi e stata rappresentata la grandezza \& la magnificenza inestimabile, nella quale si puo facilmente giudicare esser stata nobilissima \& antichissima la citta di Verona mi venne voglia di metterle in stampa \& farne parte a tutti ... \& cosi mostrar a tutto il mondo l'amplitudine \& grandezza della nostra citta.' Subsequent first eulogy on Caroto: ' '... Il Carotto alto e divino/ In cui fu sempre mai l'anima accesa/ Di far se stesso e la Patria immortale'.

57 Biadego, "Una falsa iscrizione" 86: 'Amphitheatrum nostrum, quod Arena nuncupatur, spectaculis et ludis publicis destinatum a Quinto Flaminio Romano Proconsule, ut ferunt, seu potius a Republica Veronensi conditum'. 
Scamozzi on Serlio's representation of the Arena. It seems to be copied from Caroto. ${ }^{58}$

How Leandro and others came to know the false inscription and to take it seriously, I do not know. Leandro does not reveal his reasons; instead, he cites only Sarayna as the source of his information on the antiquities of Verona. From Sarayna, he adopts inter alia the argumentation based on the false Cato that the Etruscans had founded Verona. ${ }^{59}$ But Leandro was not the only source for the dissemination of the fake inscription, because often - in all the examples cited above - a version of it that is closer to Nogarola's letter than to Leandro's guidebook was adopted (mainly the initials of the name of the consul is indicated here as 'L.Q.', instead of 'L.V.' as in Leandro). Apparently Nogarola's version was circulating in Verona and its surroundings.

\section{The Arena of Verona as a Model for the Tuscan Order of Columns}

The love for Verona inspired further historical inventions in honour of the city. For example, the actor with literary ambitions Adriano Valerini writes about the etymology of her name (1586) that 'Verona' is derived either from 'vera una, veramente unica e sola di bellezza al Mondo', surpassing Rome and all the wonders of the world, or it stems from 'verità' in the sense 'that the people of Verona are honest, which does not apply to many other peoples, especially not to those of Greece, who forever have the epithet or the gift of being deceptive and false, if it is permissible to call this vice giftedness'. ${ }^{60}$

A more important new invention was the idea to make the Arena of Verona the model for the Tuscan order of columns. It was assumed that the Etruscans adopted this order together with the Rustica, i.e. only roughly hewn stonework as at the Arena, before the Greek orders penetrated into Italy or even before they had been invented. As was usual in the Renaissance, Andrea Palladio characterizes the Tuscan order in his Quattro libri (1570) as 'the most simple and plain order, because it retains something of its early antiquity and lacks all the ornamentation that makes the others [the Greek orders] respectable and

$5^{8}$ This is proved by the accordance of the wording in contrast to other early quotes of the inscription as in the two etchings (one anonymous, dated 1558, the other by Enea Vico ca. 1550), reproduced by Schweikhart, Antichità di Verona Figs. 44-49.

6o Valerini, Bellezze di Verona 8-9: 'Molto più mi piace il nome di Verona, che di Brennona, poi che discende dalla verità, che dinota i Veronesi eßer veraci, il che die molti atri popoli non aviene, e particolarmente di quelli della Grecia, laquale ha per epiteto perpetuo, \& per dote, l'eßer mendace, e bugierda, se però è lecito che il vitio si chiami dote'. 


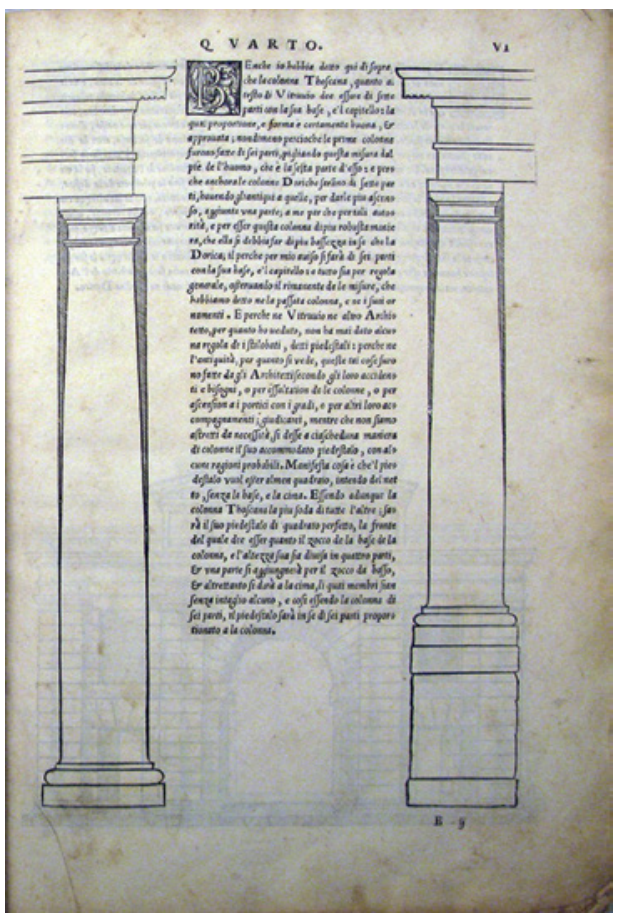

FIGURE 3.9

Tuscan Order. From: Sebastiano Serlio, Regole generali di architettura (Venice: 1537) IMAGE (C) AUTHOR

beautiful'. He bases his opinion, as he says, on 'what Vitruvius says and what can be seen in reality'. ${ }^{61}$ Indeed, the source for the design of the Tuscan order hitherto had been the description of the Etruscan temple by Vitruvius (IV, 7): The temple had columns of a simplified Doric form and above them a simple wooden beam and wooden roof. In his book on the orders of columns, Serlio replaced the wooden beam, as he had learned in Rome, with a stone entablature, which - like the column - is just a simplification of the Doric one. ${ }^{62}$ This design of the Tuscan order became obligatory until nowadays [Fig. 3.9].

$61 \quad$ Palladio Andrea, I quattro libri dell'architettura (Venice, Domenico de' Franceschi: 1570) I, 16: 'L'ordine Toscano, per quanto ne dice Vitruvio, e si vede in effetto, è il più schietto, e semplice di tutti gli ordini dell' Architettura: percioche ritiene in se di quella primiera antichità, e manca di tutti quegli ornamenti, che rendono gli altri riguardevoli, e belli'.

62 Serlio Sebastiano, Regole generali di architettura sopra le cinque maniere de gli edifici cioe, thoscano, dorico, ionico, corinthio, et composito, con gli essempi dell'antiquita, che per la magior parte concordano con la dottrina di Vitruuio (Venice, Francesco Marcolini: 1537), fols. 6 v-8 r. Günther H., "Gli ordini architettonici: rinascità o invenzione? parte seconda", in Fagiolo M. (ed.), Roma e l'antico nell'arte e nella cultura del Cinquecento (Rome: 1985) 272-310. 
In spite of his reference to Vitruvius, however, Andrea Palladio deviated from the standard design and determined the form of the Tuscan order instead by following the example of the arenas of Verona and Pola [Figs. 3.4, 3.8, and 3.10]. He confirms this explicitly, but he does not indicate concise reasons for this. ${ }^{63}$ The rich setting of the members with many profiles might rather speak against taking the elements of their articulation as a model for an order characterized by its primitivism. In building practice, Palladio never used the Tuscan order that he had conceived in theory, but adopted Serlio's version or something similar to it. Nevertheless, Scamozzi in his Idea della architettura universale (1615) followed Palladio's conception. Like Palladio, he classifies the articulation of the Arena of Verona as Tuscan and takes it as a model for his representation of the Tuscan order. However, he added a further thought to it: he inserts the Doric triglyphs in the frieze because they have evolved from the primitive wooden construction and he thinks that the Tuscan order should 'preserve the simplicity of its origins' [Fig. 3.11] ${ }^{64}$ The main reasons for Palladio and Scamozzi to use the Arena of Verona as a model for the Tuscan order were obviously the alleged very early date of its construction and its uncanonical style, which they considered a sign of premature architecture because from the view of Roman classicism it seemed primitive.

\section{$7 \quad$ Conclusion}

The various individual facts that have been examined thus far, all together prove that the souls of many natives of Venice and the Veneto were as inflamed as that of Caroto to make their nation immortal. Incited by the same patriotism, the Venetian publisher distorted Serlio's text in the second edition of the book on antique buildings because it degraded the antique monuments in the terra ferma, and a Veronese gentleman invented a fake inscription to demonstrate the old age of the Arena of his hometown; after all, Palladio and Scamozzi altered architectural theory with the same desire that, according to Scamozzi, induced the Florentines 'to adopt the Tuscan order or Rustica in

63 Palladio, I quattro libri, lib. I, 19, sustains that the arenas of Verona and Pola would have partially the same proportions as the Tuscan order; In lib. I, 14, he mentions the two arenas also as examples of the Rustica.

64 Scamozzi Vincenzo, L'Idea della architettura universal, vol. II (Venice, expensis auctoris: 1615) 53-68. 


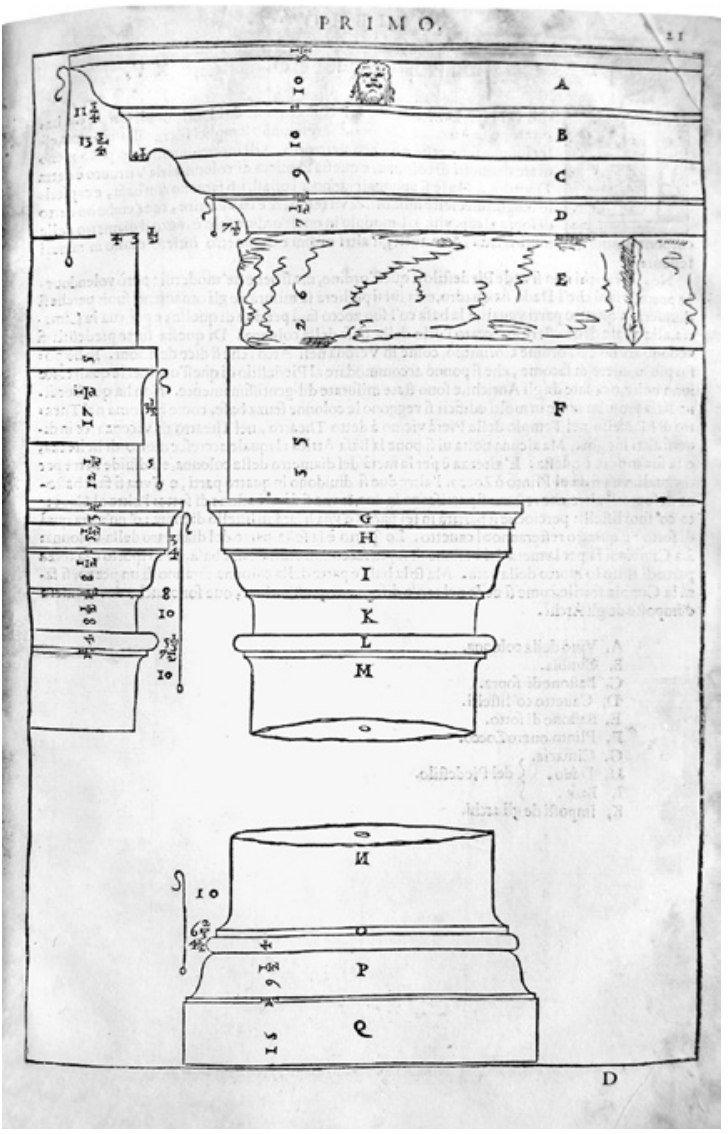

FIGURE 3.10

Tuscan Order. From: Andrea Palladio, I quattro libri dell'architettura (Venice: 1570) IMAGE (C) AUTHOR

order to preserve their former antiquity' ${ }^{65}$ The new historical classification of the Arena fended off its degradation from the classical perspective, because the violations of the classical rules were supposed to depend on the structure's early date, when architecture was still primitive. Critics might have been scandalized by them, but the advantage of the new classification of the Arena was that now Verona was the only city and the territory of Venice the only region with a great monument of the original Italian style, which was later suppressed by the foreign influence of Greece throughout Italy. Luca Pacioli had criticized Leon Battista Alberti for having neglected the Tuscan order in his architectural

65 In the indices added to the 1619 edition of Serlio's complete works Scamozzi added to the item 'Edificii d'opera Toscana, e Rustica usati assai da' Fiorentini 26.t.12.': 'secondo il Scamozzi, per mantenere la prima Antichità loro [...]'. Cf. Scamozzi, L'Idea della architettura universale, vol. II, 55 . 


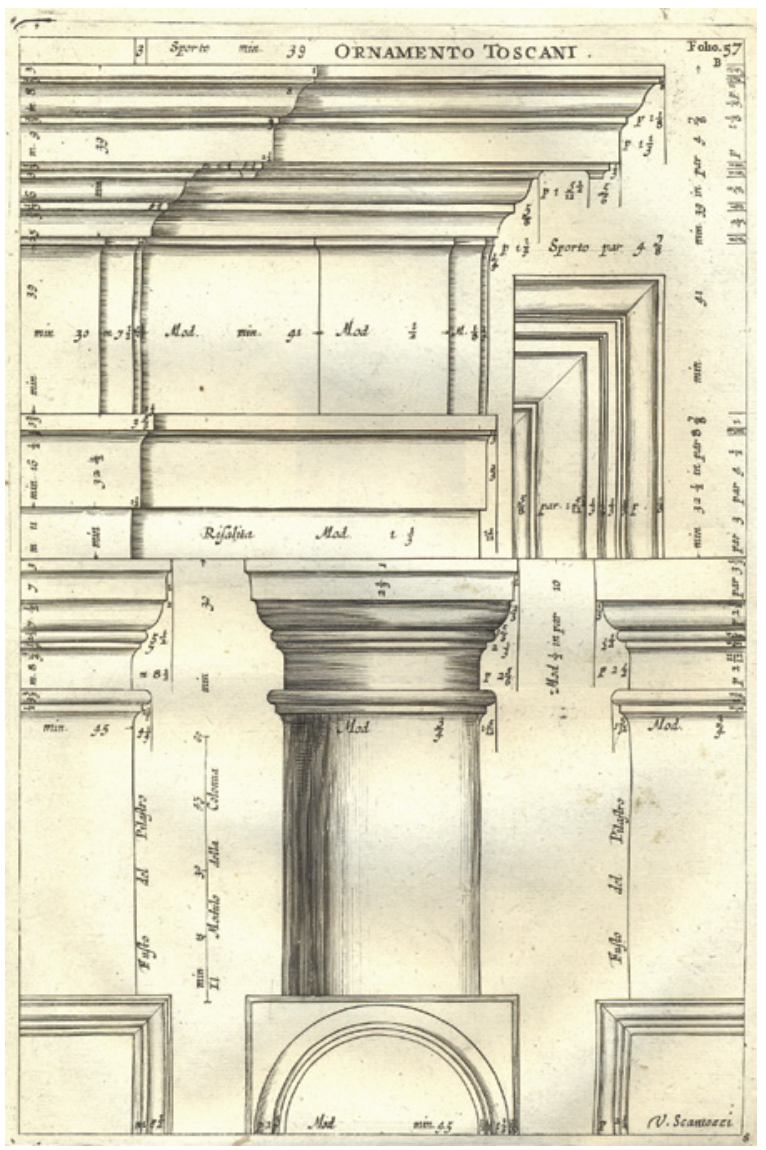

FIGURE 3.11

Tuscan Order. From:

Vincenzo Scamozzi, L'idea dell'architettura universale (Venice: 1615) IMAGE (C) AUTHOR

treatise, despite his Tuscan nationality, and thereby not respecting the 'moral example that makes it everybody's duty to fight for the fatherland' ${ }^{66}$ Palladio and Scamozzi fulfilled their patriotic duty by creating a Tuscan order after the model of the Arena of Verona. Modern historians might as well fulfil their professional duty by placing individual facts and abstract thoughts, which are handed down, in the frame of a living image of history beyond classifying them in theoretical categories.

66 'non abia osservato in essa el morale documento, qual rende licito a cadauno dovere per la patria combattere': Pacioli Luca, De divina proportione (Venice, Antonio Capella: 1509), fol. 29 v. Bruschi A. - Tafuri M. - Bonelli R. (eds.), Scritti rinascimentali di architettura, Trattati di architettura 4 (Milan: 1978) 122. 


\section{Bibliography}

\section{Scholarly Literature}

Arich D. - Spalviero F., L'Arena di Verona: duemila anni di storia e di spettacolo (Verona: 2002).

Beltramini G., "Architetture firmate nel Rinascimento italiano", in Beltramini G. Burns H. (eds.), L'architetto: ruolo, volto, mito (Venice: 2009) 49-66.

Beltramini G., "Mantegna e la firma di Vitruvio", in Marini P. - Marinelli S. (eds.), Mantegna e le arti a Verona 1450-1550 (Venice: 2006) 137-144.

Biadego G., "Una falsa iscrizione intorno all' Anfiteatro di Verona", Atti della R. Accademia delle Scienze di Torino 40 (1904-1905) 86-93.

Brown C.M., "The decoration of the private apartment of Federico II Gonzaga on the pianoterreno of the Castello di San Giorgio", in Belfanti C.M. - D'Onofrio F. Ferrari D. - Guerre C.M. (eds.), Stati e Città. Mantova e l'Italia Padana dal secolo XIII al XIX (Mantua: 1988) 315-343.

Bruschi A. - Tafuri M. - Bonelli R. (eds.), Scritti rinascimentali di architettura, Trattati di architettura 4 (Milan: 1978).

Burns H., "Le antichità di Verona e l'architettura del Rinascimento", in Marini P. (ed.), Palladio e Verona, exh. cat. (Verona: 1980) 103-118.

Coarelli F. - Franzoni L., L'arena di Verona (Verona: 1972).

Colin J., Cyriaque d'Ancône. Le voyageur, le marchand, l'humaniste (Paris: 1981).

D'Amico J., Shakespeare and Italy: The City and the Stage (Gainesville: 2001).

Esch A., "Anschauung und Begriff. Die Bewältigung fremder Wirklichkeit durch den Vergleich in Reiseberichten des späten Mittelalters", Historische Zeitschrift 253 (1991) 281-312.

Esch A., "Staunendes Sehen, gelehrtes Wissen: zwei Beschreibungen römischer Amphitheater aus dem letzten Jahrzehnt des 15. Jahrhunderts", Zeitschrift für Kunstgeschichte $5^{0}$ (1987) 385-393.

Fane-Saunders P., Pliny the Elder and the Emergence of Renaissance Architecture (Cambridge: 2016).

FischerR.(ed.), QuellenzuRomeo undJulia, Shakespeares Quellen in der Originalsprache und deutsch 2 (Bonn: 1922).

Gallerani P.I., "Andrea Mantegna e Jacopo Bellini, percorsi epigrafici a confronto", Aquileia nostra 70 (1999) 177-214.

Golvin J.-C., L'amphithéâtre Romain, vol. 1 (Paris: 1988).

Grafton A., Forgers and Critics: Creativity and Duplicity in Western Scholarship (London: 1990).

Gros P., L'architecture romaine du début du IIIe siècle av. J.-C. à la fin du Haut-Empire, vol. 1 (Paris: $2002^{2}$ ). 
Günther H., "Antike Bauten im venezianischen Hoheitsbereich. Historische Einordnung und Bewertung in der Renaissance, Einfluss auf die Säulenlehre Palladios und Scamozzis", Eirene 48 (2012) (ad honorem Jan Bazant) 60-81.

Günther H., "Badekultur in der italienischen Renaissance", in Deutsch K. Echinger-Maurach C. -Krems E.-M. (eds.), Höfische Bäder in der Frühen Neuzeit (Berlin - Boston: 2017) 25-45.

Günther H., "Gli ordini architettonici: rinascità o invenzione? parte seconda", in Fagiolo M.(ed.), Roma e l'antico nell'arte e nella cultura del Cinquecento (Rome: 1985) $272-310$.

Günther H., "Scamozzi kommentiert Serlio", Riha-Journal, Special Issue "Vincenzo Scamozzi" (November 2012), online at http://www.riha-journal.org/ articles/2012/2012-oct-dec/special-issue-scamozzi/guenther-scamozzi-kommenti ert-serlio (retrieved 12 September 2017).

Günther H., "Sebastiano Serlios Lehrprogramm”, in Boschetti-Maradi A. - Kersten W. (eds.), Fund-Stücke - Spuren-Suche, Zurich Studies in the History of Art 17/18 (Berlin: 2011) 494-517.

Höttemann B., Shakespeare and Italy (Vienna etc.: 2011), Dissertation (University of Trier: 2010).

Kimpel D. - Suckale R., Die gotische Architektur in Frankreich 1130-1270 (Munich: 1985). Krautheimer R., "Alberti's templum etruscum", Münchner Jahrbuch der bildenden Kunst $12(1961)$.

Lippmann W., "Frammenti del manoscritto inedito del IV libro dell'Idea della architettura universale: i due capitoli su teatri e anfiteatri", in Barbieri F. - Beltramini G. (eds.), Vincenzo Scamozzi 1548-1616 (Venice: 2003) 479-482.

Marchi G.P., "Ciriaco negli studi epigrafi di Scipione Maffei”, in Paci G. - Sconocchia S. (eds.), Ciriaco d'Ancona e la cultura antiquaria dell'umanesimo (Reggio nell'Emilia: 1998) 453-467.

Mitchell C., "Archaeology and Romance in Renaissance Italy", in Jacob E.F. (ed.), Italian Renaissance Studies (London: 1960) 455-483.

Mitchell C., "Felice Feliciano", Proceedings of the British Academy 47 (1961) 197-221.

Reichert F., Die Reise des Pfalzgrafen Ottheinrich zum Heiligen Land 1521 (Regensburg: 2005).

Ridolfi M., "Sopra alcuni quadri di Lucca restaurati: ragionamento quinto", Atti della R. Academia Lucchese di scienze, Lettere ed Arti 14 (Lucca: 1853) 299-391.

Sartori F., "Un fabbro umanista del '400: Francesco Corna da Soncino", in Accademia di agricoltura, scienze e lettere di Verona (ed.), Il Territorio Veronese in età Romana. Convegno del 22-23-24 ottobre 1971: atti. (Verona: 1973) 691-727.

Schweikhart G., Le antichità di Verona di Giovanni Caroto (Verona: 1977).

Signorini R., Il palazzo d'Arco in Mantova: da casa a museo (Mantua: 2016). 
Vasori O., I monumenti antichi in Italia nei disegni degli Uffizi, ed. A. Giuliano (Rome: 1981).

Weiss R., The Renaissance Discovery of Classical Antiquity (Norwich: 1988²).

\section{Books Published before 1800}

Averlino Antonio detto il Filarete, Trattato di Architettura (1461-64), eds. A.M. Finoli L. Grassi (Milan: 1972).

Avogaro Pietro Donato, De viris illustribus antiquissimis qui ex Verona claruere, ca. 1493, ed. in Avesani R., "Il 'De viris illustribus antiquissimis qui ex Verona claruere', Italia medioevale e umanistica 5 (1962).

Barbaro Daniele, I dieci libri dell'architettura di M. Vitruvio (Venice, Francesco de' Franceschi - Christoforo Chrieger: 1567).

Barozzi da Vignola Jacopo, Le due regole della prospettiva practica, ed. E. Danti (Rome, Francesco Zannetti: $\left.15^{83}\right)$.

Biondo Flavio, Italia illustrata (Basel, Officina Frobeniana: 1531).

Biondo Flavio, Le historie da la declinatione de l'Impero di Roma insino al tempo suo, trans. L. Fauno (Venice, Michele Tramezzino: 1543-1550), vol. 1.

Caroto Giovanni, De le antiquità de Verona con nuovi agionti (Verona, Paolo Ravagnan: $1560)$.

Cato M. Porcius, "Fragmenta ex libris originum", in Fragmenta vetustissimorum auctorum summo studio ac diligentia nunc recognita, ed. Annio da Viterbo (Basel, Johannes Bebel: 1530).

Ciriaco d'Ancona, Itinerarium, ed. Laurentius Mehus (Florence, Giovanni Paolo Giovannelli: 1742).

Corna da Soncino Francesco, Fioretto de le antiche croniche de Verona e de tutti i soi confini e de le reliquie che se trovano dentro in ditta citade (1515), eds. G.P. Marchi P. Brugnoli (Verona: 1973).

Fichard Johann, Italia (1536), ed. J.C. von Fichard, Frankfurterisches Archiv für ältere deutsche Litteratur und Geschichte 3 (1815).

Maffei Scipione, Verona illustrata (Verona, Jacopo Vallarsi e Pierantonio Berno: 17311732), vol. 4.

Meisterlin Sigismund, Ein schöne Cronick und Hystoria, wye nach der Synndtfluß Noe die teutschen, das streitpar volck, iren anfang enpfangen haben (Augsburg, Melchior Ramminger: 1522).

Nanni Giovanni, Le antichità di Beroso Caldeo sacerdote. Et d'altri scrittori cosi Hebrei, come Greci, Latini, che trattano delle stesse materie, trans. F. Sansovino (Venice, Altobello Salicato: 1583).

Pacioli Luca, De divina proportione (Venice, Antonio Capella: 1509). 
Palladio Andrea, I quattro libri dell'architettura (Venice, Domenico de' Franceschi: 1570).

Panteo Giovanni Agostino, De laudibus Veronae (Venice, Bernardino Vitali: 1505).

Panvinio Onofrio, Antiquitatum Veronensium libri VIII (Passau, Paolo Frambotto: 1648).

Philandrier Guillaume, In decem libros M. Vitruvii Pollionis de architectura annotationes (Rome, Giovanni Andrea Dossena: 1544).

Sanudo Marino, Itinerario di Marin Sanuto per la terraferma Veneziana nell'anno 1483, ed. R. Brown (Padua: 1847).

Sarayna Torello, De origine et amplitudine civitatis Veronae (Verona, Antonio Putelleti: 1540).

Scamozzi Vincenzo, L'Idea della architettura universale, vol. 2 (Venice, Expensis Auctoris, per Valentino Giorgio: 1615).

Serlio Sebastiano, Regole generali di architettura sopra le cinque maniere de gli edifici cioe, thoscano, dorico, ionico, corinthio, et composito, con gli essempi dell'antiquita, che per la magior parte concordano con la dottrina di Vitruuio (Venice, Francesco Marcolini: 1537).

Serlio Sebastiano, Il terzo libro, nel qual si figurano e descrivono le antiquita di Roma e le altre che sono in Italia e fuori d'Italia (Venice, Francesco Marcolini: 1544).

Sigonio Carlo, Historiarum de Occidentali Imperio libri XX (Basel, Thomas Guarini: 1579).

Valerini Adriano, Le bellezze di Verona. Nuovo ragionamento (Verona, Girolamo Discepoli: 1586). 